\title{
How to Enhance the Impact of Perceived Organizational Support on Knowledge Sharing? Evidence from Higher Education Sector
}

\author{
Yaser Mutahar ${ }^{1}$, Mazen Mohammed Farea ${ }^{2}$, Mohammed Abdulrab*3,4, Yaser \\ Hasan Al-Mamary ${ }^{4,5}$, Adel Abdulmhsen Alfalah ${ }^{6}$, Mohieddin Grada ${ }^{7}$, \\ Khalid H. Alshammari ${ }^{8}$ \\ ${ }^{1,2}$ Faculty of Finance and Administrative Sciences, Al-Madinah International \\ University \\ ${ }^{3}$ Business Department, Community College of Qatar, Doha, Qatar \\ ${ }^{4}$ Department of Business Administration, Faculty of Administrative and Humanities \\ Sciences, Al-Razi University, Sana'a, Yemen \\ 5,67,8 College of Business Administration, University of Ha'il, Ha'il, Saudi Arabia \\ yasermotahar@gmail.com; mazen.farea@mediu.edu.my; *abdulrabd@gmail.com; \\ yaser_almamary@yahoo.com; a.alfalah@uoh.edu.sa;m.grada@uoh.edu.sa; \\ Khha.alshammari@uoh.edu.sa
}

\begin{abstract}
Academics in the new millennium are not only required to do academic work, current events in universities in Malaysia suggests academics are required to perform additional tasks such administration work, consultation, and avail themselves to perform any tasks intended to meet the demands of their faculty or university. These tasks are considered as the academics' commitment to contribute to their university and country's overall development that increases the ranks of their educational institutions in the world's top university rankings. These tasks also require knowledge sharing among academics. The occurrence of these activities are determined by the perception of Academics towards their institutions. This study explored the influence of adopting Organizational Citizenship Behavior as a mediator in the relationship between Perceived organizational Support and knowledge sharing among academics. The study was conducted in Malaysia and data collected from academics in the five major research universities. Quantitative research design was adopted where Pearson correlation, multiple regression analysis and factor analysis were used to measure the relationships hypothesized. The results indicated that Perceived Organizational Support does not have any significant effect on knowledge sharing among academics in the Malaysian higher educational sector; and organizational
\end{abstract}


citizenship behavior improves the relationship between Perceived Organizational Support and knowledge sharing hence, $\mathrm{H} 1$ was rejected, while $\mathrm{H} 2$ and $\mathrm{H} 3$ supported. The findings suggested that adopting measures of organizational citizenship actions including employee opinion, well-being, goals and values enables positive behavior within an institution and ensure increased knowledge sharing among academics. Suggestions for future researchers includes adopting qualitative research design to collect unregulated data from academics and measure their true opinions.

Keywords: Organizational Citizenship behavior, perceived organizational Support, knowledge sharing, academics, higher education

\section{Introduction}

Academics have the fundamental role of teaching, research, and community service and majority of these roles involve sharing data, information, and knowledge. Since these roles are performed in institutions, it is unavoidable to admit these events necessitate sharing knowledge especially among academics. Academic institutions are part of the educational system and their structure are a source of attraction to both students and academics enrolment and application into programs. Malaysia is one of the emerging economies that promotes its educational system to attract academics from all over the world and their global ranks has increased in areas such as published researches, patents, and the quality of institutions (Economic Transformation Programme (ETP), 2017). The Government of Malaysia has invested many resources in the education sector due to the believe that education contributes to its objective of transforming the country from a middle-income into a high-income country by 2020 (Blueprint, 2019). In addition, the sector has undertaken several strategic and proactive programs aimed at making Malaysia a hub for excellent international education that promotes its domestic and international educational recognitions. This objective has therefore contributed to The Ministry of Higher Education (MOHE) and other relevant educational bodies formulate policy reforms to enable achieving these objectives. These action also contributed to the MOHE recognising five research institutions for their value and new knowledge creation with the focus on both quantity and quality of outcomes such as; research, researchers, postgraduates, innovation, networking and linkages and supporting facility. The five universities selected by The Ministry of Higher Education (MOHE) are; Universiti Malaya, Universiti Sains Malaysia, Universiti Kebangsaan Malaysia, Universiti Putra Malaysia and Universiti Teknologi Malaysia.

Knowledge creation and sharing emerged primarily in the early 1980s with its first publishers suggesting its necessity for generating intellectual capital, contributing to technological inventions and development of knowledge based economy (Seonghee \& Boryung, 2008). Until recently, there are over 13000 publications on the concept of knowledge sharing identified from the Scopus database though only few studies were identified to relate to the higher educational 
Institutions worldwide. Some previous literatures confirmed the contribution of knowledge sharing to effectiveness. Khari \& Sinha (2018) confirmed in their study how knowledge sharing is an importance source of competitive advantage for organisations and countries in generating and improving effectiveness. The earlier studies of by (Jolaee, Nor, Khani, \& Yusoff, 2014) also established the importance of knowledge sharing in Malaysia where they argued the employee's willingness to share individual knowledge translates into organisational knowledge sharing and this drives innovation among staffs and contribute to overall improvement in organisational performance. Related studies have indicated the importance of factors such as social media and computer systems in contributing to knowledge sharing among academics in countries such as Malaysia, United Kingdom, and The Kingdom of Saudi Arabia (Alshahrani, H., \& Rasmussen Pennington, D., 2018).

The emerging academic environment requires collaborative research and an environment that enables members of Higher Education Institutions to share knowledge, this further requires the willingness of academics to share knowledge. The major problems identified by several empirical studies is the challenge of accessibility to information, since every organization depends on information and knowledge for its survival. The world continues to evolve and develop new methods and this has complicated the nature of knowledge sharing where employees are not only required to attain knowledge but are expected to put it into action, effectively and efficiently share knowledge. The main role of academics include research and teaching and these duties are fundamental part of sharing existing knowledge or developing new knowledge. The modern research and academic based environment involves review of existing knowledge and updates of previous knowledge to reflect emerging trends, which also requires willingness of academics to share knowledge. However, recent events suggests the experiences of academics in their educational institutions discourage knowledge sharing (Ghasemy, et al., 2018). A recent study by Fauzi, et al, (2018) supported this assertion and attributed the unwillingness of academics to share knowledge to the lack of trust and the past events experienced by the academics within their universities, this data was collected from Malaysian academics. Tafti, H. F., Sarvestani, R. A., \& Hosseini, M. (2018) further attributed this problem to the lack of mutual understanding among academics in the performance of their roles, they further added this was as a result of lack of subjective norm and mutual trust among academics in the same value networks in Malaysia. Failure of institutions to share relevant knowledge with their academic staffs also contributes to poor perception of academic staffs about their research institutions (Akosile, A.\& Olatokun, 2019). Furthermore, knowledge sharing behavior is hampered where the academic staff perceive no support from their institutions in adding success to their organization hence both institutions and their academics failure to share relevant knowledge compounds the existing problem the present study attempts to study. 


\section{Literature Review}

The role of academics in the emerging knowledge based economy continue to grow significantly where higher educational institutions are tasked with contributing to national economic and social development by attracting high number of postgraduates both locally and internationally. Malaysian universities are no exception, the sector plays an important function in contributing to the economic transformation intended to make the country a high income nation by 2020 (Economic Transformation Programme Annual Report, 2017). This has become a national agenda and captured in the Malaysian National Higher Education Strategic Plan (2015-2025), with the objective of becoming the international hub of higher education excellence (ETP Annual Report, 2017). The five primary research institutions in Malaysia were established by the Ministry of Higher Education contribute to a change in the global rank status of education in Malaysia and become a world class destination for higher education as indicated in the Malaysian National Higher Education Strategic Plan Beyond 2020. The primary role of these five research universities was to focus on both quantity and quality of outcomes such as; research, researchers, postgraduates, innovation, networking and linkages and supporting facility. They were also to contribute to generating intellectual capital, advancing technological inventions, efficiently participating in development of knowledge -based economy and developing knowledge linking activities which aim at improving scientific and technological transfer and commercialization. There were challenges reported by earlier studies on the Malaysian educational sector which hampered achieving the objective for which they were established; beaucratization (Azman et al. 2011), work related stress of Malaysia academic staffs (Han, S. H., et al., 2016), high turnover (Mousa., T. S., et al., 2019). Wu and Zhu (2012) suggested adopting the best practices of knowledge sharing to contribute to permanent solution to these challenges and keep organisations going on. Therefore the study further highlights the key assumptions in the dimensions of this study (perceived organizational support, organizational citizenship behaviour) and their relationship with knowledge sharing.

\subsection{Perceived organizational support}

The concept of Perceived organizational support (POS) was concluded in the study of Eisenberger, R., Huntington, R., Hutchison, S., \& Sowa, D. (1986).) as the degree of perception individuals have regarding how they are valued and treated by their organization, this study further added that employees perceiving such support from their organization demonstrates the level with which their contributions and well-being are valued within such organization. D. G. Allen, Shore, and Griffeth (2003) suggested that Perceived organizational Support leads to better performance by employees as they become loyal to the organization and also develop emotional attachment to the organization. The research of C.-W. Jeung, H. J. Yoon, and M. 
Choi (2017) concluded that Perceived organizational Support influences knowledge sharing where the organization concentrates on promoting the psychological state of mind of its employees, and reward how much emotional attachment employees demonstrate towards the organization. The relationship between Perceived organizational Support and knowledge sharing was found positive in the research of L. Lu, Leung, and Koch (2006); E. F. Cabrera and Cabrera (2005). These assertions were supported in recent studies that investigated the influence of factors such as (individual absorptive capacity, culture, emotional arousal, and persuasion) on knowledge sharing (Fullwood, Rowley, \& McLean, 2018)

\subsection{Organizational citizenship behavior}

According to Abdulrab et al. (2020) OCB refers to behaviors or actions that are regarded as extra-role instead of in-role and must be discretionary in nature, implying that they are not part of an individual's formal specified tasks. According to Al-Mamary (2020) Organizational citizenship behaviour plays an important determining role that contribute to the overall organizational effectiveness and the way it leads organizations towards success in the intense competitive business environment. There Organizational Citizenship Behavior was referred to by Organ (1988) as a type of personal behavior which is non-mandatory and not recognized by the formal reward system neither directly nor explicitly. Such behavior though tends to promote the efficient functioning of the organization, are described as discretionary in nature. Previous studies concluded on the existence of a relationship between organizational citizenship behavior and knowledge sharing (I. Ahmad \& Zafar, 2018; Sadegh et al., 2018). The findings of these studies based on evidence supported the adoption of Organizational Citizenship Behavior as a mediator in the relationship between variables including perceived organizational support and knowledge sharing. Further, such relationship can be explained by the application of the Social Exchange Theory (Blau, 1968) which therefor suggests that there are interrelationships among certain individual behaviors and attitudes, such an where an individual or employee perceives a high level of support and trust from his or her organization, it leads to awareness that encourages high performance levels beyond their mundane responsibilities.

\subsection{Knowledge sharing}

According to Matar (2018) no wonder that the world's economy is referred to as a knowledge economy, where the intellectual capital of organizations is the real fortune they possess. According to Alwaheeb et al. (2020) knowledge sharing is an important resource to achieve competitive advantage and increase innovation, and sharing knowledge help in building efficient performance of environments of higher education and it plays a significant role in universities. J.-N. Lee (2001) defined knowledge sharing as behavior of disseminating or transferring knowledge from 
one an individual, group or organization to another. Thus, J.-N. Lee (2001) concluded that the degree to which knowledge sharing can be communicated is either orally, symbolically or in a written form. Knowledge sharing as a term is often characterized as an essential part of the knowledge management frameworks, G. Kim and W. Bock (2002). E.Davenport and Cronin (2000) refer to the university as the most common place for knowledge development. Considering universities as the key source of development of information and the place where the initial implementation of knowledge management took place. Hence universities are the most anticipated place where more specifically academics can exchange information freely among its members. Further, university sharing knowledge occurs when academics understand the value of sharing information and its ultimate outcome according to Ridzuan, Sam, and Adanan (2008). Annansingh et al .( 2018) refer to institutions of higher education as the place to establish the distribution, sharing and exchange of knowledge governed by relationships between individuals, technologies and processes. The sharing of knowledge in institutions of higher education leads to better services and results.

\subsection{Hypothesis}

Based on the literature presented, the present study therefore came out with the following hypotheses:

H1: Perceived organizational support has positive effect on academics' knowledge sharing.

H2: Perceived organizational support has positive effect on academics' organizational citizenship behavior.

H3: Organizational Citizenship Behavior mediates the relationship between Perceived Organizational Support and knowledge sharing.

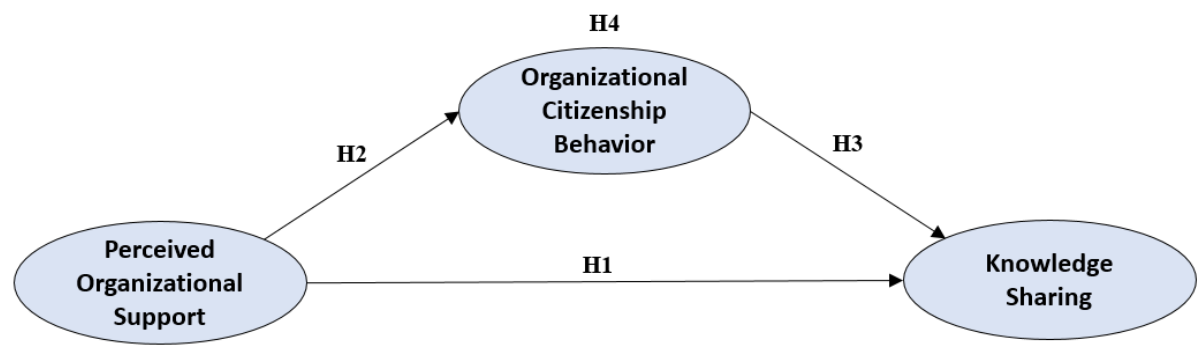

Fig. 1: depicts the research model for this study

\section{Research methodology}

\subsection{Research Design}

The data of the study was collected with an instrument (questionnaire) adopted and 
adapted from previous studies. The items were adopted using a five point Likert scale. This instrument was tested in Malaysia among academics in similar studies conducted by previous researchers (Abdulrab et al., 2018; Chuymanee \& Sorod, 2018). The data was collected from respondents who are academics in the five research universities in Malaysia (Universiti Malaya, Universiti Sains Malaysia, Universiti Kebangsaan Malaysia, Universiti Putra Malaysia and Universiti Teknologi Malaysia). Subject Matter Experts were utilized to review and assess the questionnaire for its clarity, understandability and the extent to which the instruments measure what it is intended to measure. Modifications were therefore made prior to the major data collection.

Table 2: Summarizes the distribution of the questionnaires in the study.

\begin{tabular}{|l|l|}
\hline \multicolumn{1}{|c|}{ Response Rate } & \\
\hline Questionnaires Distributed & 500 \\
\hline Returned & 388 \\
\hline Unusable Questionnaires & 8 \\
\hline Returned and Usable & 380 \\
\hline Not Returned & 112 \\
\hline Response Rate & $78 \%$ \\
\hline Usable Response Rate & $76 \%$ \\
\hline
\end{tabular}

The above table summarizes the study's distribution, collection and functional data. This study's sample size $(\mathrm{N}=380)$ is considered sufficient to achieve an acceptable degree of statistical power in Smart-PLS, as it is above the minimum criterion (10 times rule: 10 times the number of independent variables) (Joseph F. Hair, Hult, Ringle, \& Sarstedt, 2017). The study adopted Statistical Package for the Social Sciences (SPSS) for analysis of descriptive data using central tendency, dispersion and frequency distribution. Smart-PLS software was adopted to test the study hypotheses and overall framework using Structural Equation Modelling (SEM).

\subsection{Reliability}

The reliability of the method used in this study will be tested by checking the accuracy of responses (Nunnally, 1978). The validity of this research will also be checked by prior literature review as the source of questions, analysis of factors will be done in the same vein, and this type of analysis is a methodology especially appropriate for handling a variety of variables in evaluating the associations between these variables. The primary aim is to summarize a smaller number of factors with the data found in a large number of variables. This methodology explores the numerical existence and structure of the underlying factors that, when it comes to the factor matrix, affect the relationships between the set of variables, 
this is the coefficient table that expresses the relationships between the included variables and factors. The "factor loadings" define these elements of the factor matrix. Table 3 shows the reliability of the instruments.

Table 3: The reliability of the instruments

\begin{tabular}{|c|c|}
\hline Variables & Cronbach's Alpha \\
\hline Knowledge sharing & 0.968 \\
\hline Perceived Oganizational Support & 0.968 \\
\hline Oganizational Citizenship Bbehaviour & 0.988 \\
\hline
\end{tabular}

In addition, the reliability can be evaluated by the use of the internal reliability (Cronbach alpha $\geqslant 0.70)$ and construct reliability $(C R \geqslant 0.70)$ (Al-Mamary et al., 2020). Table 6 below shows the measures of reliability of a measurement model.

\subsection{Validity}

Validity refers measures accuracy in performing their tasks and how accurate these measures are (Sekaran, 2000). In other words it can be considered as the reflection of the items to the constructs (Hair, 2006) the more the items and theoretical construct are appropriate, the better validity researcher will get. The questionnaire was emailed to five experts in the study's area. They were asked to review and evaluate the questionnaire. They were also asked for their opinions on the degree to which the questionnaire items were explicit and the degree to which they were appropriate to determine the aspects for which they were intended. They were also asked if they could provide the researcher with more feedback on making any changes in terms of the phrases to the questionnaire items to make them clearer and more informative. Useful input was received concerning language usage, phrasing, and the items' wording. Based on the feedback given by the participants, the final questions were updated and all the listed items were changed to suit the research context.

\section{Results and discussion}

The data was tested for outliers using Mahalanobis score where a score greater than the critical value is considered as an outlier and therefor removed from any further analysis. The result showed that there are no multivariate outliers in the data set in this study. The normality of the 3 constructs was checked and the result indicated that there is no violation. Thus, all variables in this study are categorized as normally distributed.

The standard deviations and means of study variables are shown in Table 4 below 
indicating that Knowledge sharing reported the highest mean score of 3.77 out of 5.0 , with a standard deviation of 0.965 , suggesting that respondents agreed that sharing knowledge is important to them and that they are certain in the competence and fairness of their fellow academics they share knowledge with. In addition, they consider sharing their knowledge and experience as a major contribution to their universities. Organizational citizenship behavior earned a mean score of 3.6 out of 5.0, with a standard deviation of 1.38, suggesting that most respondents decided to display sincere consideration and courtesy, and sportsmanship towards colleagues, even in the most challenging business or personal circumstances, and defended the university when criticized by others.

Table 4: Descriptive statistics for the studied variables

\begin{tabular}{|c|c|c|c|c|}
\hline $\begin{array}{l}\text { First-order } \\
\text { Constructs }\end{array}$ & Second-order Constructs & Indicators & Mean & $\begin{array}{l}\text { Standard } \\
\text { Deviation }\end{array}$ \\
\hline & $\begin{array}{l}\text { Perceived Organizational } \\
\text { Support (POS) }\end{array}$ & $\begin{array}{l}\text { POS1 } \\
\text { POS2 } \\
\text { POS3 } \\
\text { POS4 } \\
\text { POS5 } \\
\text { POS6 } \\
\text { POS7 } \\
\text { POS8 }\end{array}$ & 3.092 & 1.302 \\
\hline $\begin{array}{c}\text { Organizational } \\
\text { Citizenship } \\
\text { Behaviour - } \\
\text { Individual } \\
\text { (OCBI) }\end{array}$ & & $\begin{array}{l}\text { OCBI1 } \\
\text { OCBI2 } \\
\text { OCBI3 } \\
\text { OCBI4 } \\
\text { OCBI5 } \\
\text { OCBI6 } \\
\text { OCBI7 } \\
\text { OCBI8 }\end{array}$ & 3.74 & 1.37 \\
\hline \multirow[t]{3}{*}{$\begin{array}{l}\text { Organizational } \\
\text { Citizenship } \\
\text { Behaviour - } \\
\text { Organization } \\
\text { (OCBO) }\end{array}$} & & $\begin{array}{l}\text { OCBO1 } \\
\text { OCBO2 } \\
\text { OCBO3 } \\
\text { OCBO4 } \\
\text { OCBO5 } \\
\text { OCBO6 } \\
\text { OCBO7 } \\
\text { OCBO8 }\end{array}$ & 3.486 & 1.38 \\
\hline & $\begin{array}{c}\text { OrganizationalCitizenship } \\
\text { Behaviour (OCB) }\end{array}$ & $\begin{array}{l}\text { OCBI } \\
\text { OCBO } \\
\end{array}$ & 3.6 & 1.38 \\
\hline & Knowledge Sharing (KS) & WC & 3.77 & \\
\hline
\end{tabular}




\begin{tabular}{|c|c|l|l|c|}
\hline $\begin{array}{l}\text { First-order } \\
\text { Constructs }\end{array}$ & Second-order Constructs & Indicators & Mean & $\begin{array}{c}\text { Standard } \\
\text { Deviation }\end{array}$ \\
\hline & & $\begin{array}{l}\text { KOC } \\
\text { CP } \\
\text { PI }\end{array}$ & & 0.965 \\
& & & \\
\hline
\end{tabular}

The Pearson coefficient was used to explore the intensity and direction of the study variables relation. The interpretation of the relationship between variables understood is as follows, based on the findings of the correlation analysis in Table 5 below;

f) Relationship between organizational citizenship behavior with perceived organizational support.

Table 4 indicated that organizational citizenship behaviour is positive and have significant relationship with perceived organizational support. The correlation coefficient was 0.326 and this indicate that the relationship is moderate

j) Relationship between knowledge sharing with organizational citizenship behavior

Table 5: Correlation between factors

\begin{tabular}{|l|l|l|l|}
\hline & \multicolumn{1}{|c|}{ POS } & \multicolumn{1}{c|}{ OCB } & \multicolumn{1}{c|}{ KS } \\
\hline Perceived Organizational Support & 1 & & \\
\hline Organizational Citizenship Behaviour & $.326^{* *}$ & 1 & \\
\hline Knowledge Sharing & $.509^{* *}$ & $.614^{* *}$ & 1 \\
\hline
\end{tabular}

**. Correlation is significant at the 0.01 level (2-tailed).

Table 5 above indicated that knowledge sharing is positive and have significant relationship with organizational citizenship behaviour. The correlation coefficient was 0.614 and this indicate that the relationship is moderate.

The analysis of construct reliability was done using Cronbach's Alpha coefficients and composite reliability tests. This result indicated adequate internal reliability of the measures used in this study show in the Table 6 below.

Table 6: Cronbach's alpha and composite reliability

\begin{tabular}{|l|c|c|c|}
\hline \multicolumn{1}{|c|}{ First-order Constructs } & Second-order Constructs & $\begin{array}{c}\text { Cronbach's } \\
\text { alpha } \\
\mathbf{( > 0 . 7 )}\end{array}$ & $\begin{array}{c}\text { Composite } \\
\text { Reliability } \\
(>\mathbf{0 . 7})\end{array}$ \\
\hline & $\begin{array}{c}\text { Perceived Organizational } \\
\text { Support (POS) }\end{array}$ & 0.968 & 0.973 \\
\hline $\begin{array}{l}\text { Organizational Citizenship } \\
\text { Behaviour - Individual (OCBI) }\end{array}$ & & 0.981 & 0.984 \\
\hline $\begin{array}{l}\text { Organizational Citizenshipm } \\
\text { Behaviour - Organization (OCBO) }\end{array}$ & & 0.976 & 0.979 \\
\hline
\end{tabular}




\begin{tabular}{|l|c|c|c|}
\hline & $\begin{array}{c}\text { Organizational Citizenship } \\
\text { Behaviour (OCB) }\end{array}$ & 0.988 & 0.989 \\
\hline Written contribution (WC) & & 0.921 & 0.942 \\
\hline $\begin{array}{l}\text { Organizational communication } \\
\text { (KOC) }\end{array}$ & & 0.924 & 0.939 \\
\hline Community of Practice (PC) & & 0.972 & 0.977 \\
\hline Personal Interaction (PI) & & 0.955 & 0.962 \\
\hline & Knowledge Sharing (KS) & 0.968 & 0.970 \\
\hline
\end{tabular}

In the structural assessment, the path coefficients and R2 values were examined first. In other words, after computing the path estimates in the structural model, a bootstrap analysis was performed for the purpose of assessing the statistical significance of the path coefficients. Path coefficients represent the relationships among the constructs which are hypothesized in the study. If the standardized values of path coefficients are close to +1 , it means that there is a strong positive relationship which is almost significant (Joseph F Hair et al., 2014). Thus, the path coefficients for this study were produced as shown in Table 6 below

Table 7: Structural assessment results

\begin{tabular}{|c|c|c|c|c|c|c|}
\hline Hypotheses & Relationship & Beta & Std Error & T -value & P Values & Decision \\
\hline H1 & POS $\rightarrow$ KS & 0.057 & 0.051 & 1.104 & 0.308 & Not Supported \\
\hline H2 & POS $\rightarrow$ OCB & 0.472 & 0.036 & 13.056 & 0.000 & Supported \\
\hline H3 & OCB $\rightarrow$ KS & 0.428 & 0.068 & 6.283 & 0.000 & Supported \\
\hline
\end{tabular}

Key: POS: Perceived Organizational Support, OC: Organizational Citizenship Behaviour, KS: Knowledge Sharing

Note: $*=\mathrm{p}<0.05, * *=\mathrm{p}<0.01$

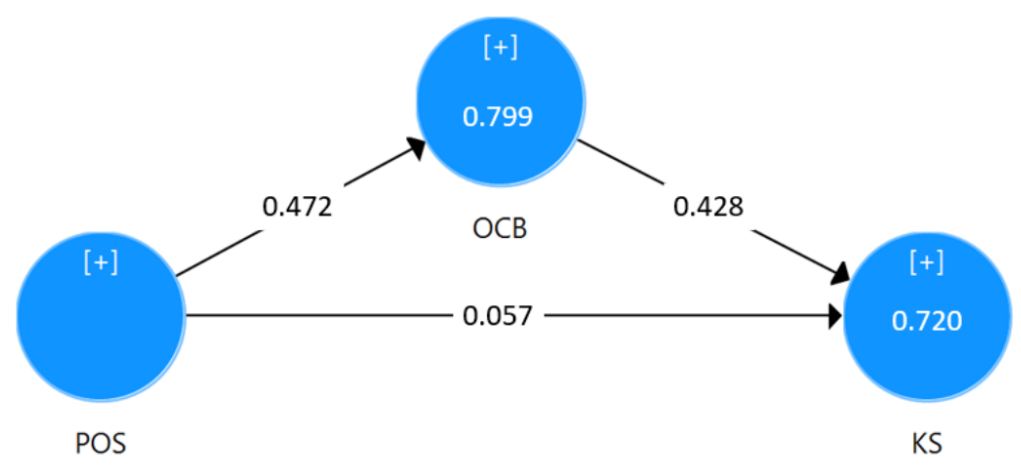

Fig. 2: Structural model for this study

The structural model assessment as shown in Figure 2 and Table 7 provides an indication of the hypothesis tests, with five direct hypotheses. POS does not appear to be a significant predictor of $\mathrm{KS}(\mathrm{b}=0.057, \mathrm{t}=1.104, \mathrm{p}>0.05=0.308)$. Hence, $\mathrm{H} 1$ is not supported. POS significantly predicts OCB $(\mathrm{b}=0.472, \mathrm{t}=13.056, \mathrm{p}<0.005)$. 
Hence, H2 is supported. Furthermore, the result showed that POS, explained $79.9 \%$ of the variance in OCB. POS, and OCB also explained $72.0 \%$ of the variance in $\mathrm{KS}$.

Table 8: R2 of endogenous latent variables

\begin{tabular}{|l|c|l|l|}
\hline \multirow{2}{*}{ Construct } & \multirow{2}{*}{$\mathbf{R}^{2}$} & \multicolumn{2}{c|}{ Result } \\
\cline { 3 - 4 } & & Cohen (1988) & Chin (1998b) \\
\hline Organizational Citizenship Behaviour & 0.799 & Substantial & Substantial \\
\hline Knowledge Sharing & 0.720 & Substantial & Substantial \\
\hline
\end{tabular}

Overall, three hypotheses were examined in this research. Out of these three, two hypotheses were accepted and only one hypothesis was rejected.

Table 9: Summary of Hypotheses Testing

\begin{tabular}{|c|c|}
\hline Hypotheses Direct Relationships & Result \\
\hline $\begin{array}{l}\text { There is a significant effect of Perceived Organizational Support on } \\
\text { Academics' Knowledge Sharing in Malaysian Research Universities. }\end{array}$ & Not Supported \\
\hline $\begin{array}{l}\text { There is a significant effect of Perceived Organizational Support on } \\
\text { Organizational Citizenship Behavior among Academics in Malaysian } \\
\text { Research Universities }\end{array}$ & Supported \\
\hline $\begin{array}{l}\text { There is a significant effect of Organizational Citizenship Behavior on } \\
\text { Knowledge Sharing among Academics in Malaysian Research } \\
\text { Universities }\end{array}$ & Supported \\
\hline \multicolumn{2}{|l|}{ Mediating Variable } \\
\hline $\begin{array}{l}\text { Organizational Citizenship Behavior mediate the relationship between } \\
\text { Perceived Organizational Support and knowledge sharing }\end{array}$ & Supported \\
\hline
\end{tabular}

The aim of this study is to determine the impact of perceived organizational support on sharing of knowledge among academics within Malaysian institutions of higher education. The study restricts its reach to the Universiti Malaya (UM), Universiti Sains Malaysia (USM), Universiti Kebangsaan Malaysia (UKM), Universiti Teknologi Malaysia (UTM), and Universiti Putra Malaysia (UPM), which are Malaysian academic institutions. Perceived organizational support is an exogenous variable which was analyzed and have no significant effect on knowledge sharing. The result indicated that a change in Perceived Organizational Support does not result in a major shift in the sharing of Knowledge. The Organizational Citizenship Behavior Mediation Test between Perceived Organizational Support and knowledge Sharing suggested that there is a complete mediation impact $(=0.202, \mathrm{t}=4.927)$, in line with the bootstrapping approach guidelines (Preacher \& Hayes, 2008). Therefore, the study's findings contradict similar studies by van Knippenberg, van Prooijen, and Sleebos (2015), where POS had a major impact on OCB. This was endorsed in the studies of, Pattanayak, Mishra, and Dash (2017) where similar studies were carried out within the public sector of India. 
Recent studies have indicated that, although Perceived organizational support has been massively researched, there are limited studies in the area of the academic setting and in the context of the Malaysia academic. The study of Zhou and Zhang (2013), and Jolaee et al., (2014) conducted similar study however they did not study the direct effect of POS on KS. Related studies of Perceived Organizational Support was adopted as a predictor of Organizational citizenship behavior and fully mediate the relationship was conducted by (R. Zhang, 2011). The findings of the present study suggests that organizational citizenship behavior improves the relationship between perceived organizational support and knowledge sharing. The present study for this reason presents the finding that the academic staff sampled for the analysis in the Malaysian research universities do not perceive organizational support that has contributed to their untoward actions to their organization. Therefore, this suggests universities relook at the measures they adopt in shaping the perception of their academic staffs towards knowledge sharing. The Malaysian higher educational sector though remains competitive in its quest for higher global ranks and quality and quantity of research and researchers must there create an environment to enable good citizenship behavior towards the objective of achieving knowledge sharing.

\section{Conclusion}

The present study identifies the predictor that is expected to encourage knowledge sharing among academics within the Malaysian higher educational sector. Adopting the benefits of organizational citizenship behavior brings significant social change by leading to increased knowledge sharing among academics. The study results suggested that perceived organizational support helps academics to have a good attitude through their moral responsibility, beliefs, and planned activities within the university community. Malaysian education system has always been a driving force for growth and transformation and therefore the findings of this study can help Malaysian research university leaders achieve higher growth and transformation by adopting leadership and management styles that allow the sharing of knowledge and influence the psychological empowerment and organizational citizenship behavior of academic staff.

In building confidence among academics within Malaysian research universities, the present study suggests enhancing working teams, work participation, citizenship behaviour, working relationships, and sealing the knowledge divides among academics. This will thereby enhance university performance and efficiency in the educational sector. Research by its nature depends on other works from previous researchers, which suggests adopting and utilizing approaches that promotes excellence in this intellectual activity therefore there is the need for trust and dependence of works thus the present study not only focus on academics but also leadership in these academic institutions such as the Higher Education Leadership 
Academy (AKEPT), to develop plans and actions to be followed by academics in institutions which will further promote academic knowledge sharing among institutions.

Academics are not only needed to do academic work in the new millennium, current events at universities in Malaysia suggest that academics are required to undertake additional tasks such as administration work, consultation and make use of any tasks designed to meet the demands of their faculty or university. These tasks are considered as the dedication of the academics to contribute to the overall growth of their university and country, and to increase the ranks of their staff and educational institutions in the top university ranking in the world. These tasks often enable academics to share knowledge, therefore it is important for the future academic to focus on achieving a balance between these tasks and their effect on the academics' ability to grow and share knowledge to achieve both the institutional objective of high ranking academics worldwide and the personal academic objectives. In doing so, the future academic will the effects of these additional tasks and whether they contribute to the organizational performance or academic confidence. According to Brante \& Sloka, (2021) education is becoming more and more important in development of national economy and ensuring competitiveness of the economy of the respective country.

The finding of the present study allows for the evaluation of internal organizational variables that quantify employee perspective on the supports offered by the institution. In the case of a research organization, the results of this study will form the basis for defining interventions that workers consider their institutions to be adequate help. This will provide academic institutions with places for change to ensure that academics are dedicated to their organizations, and the resulting impact seen in their citizenship actions such as going extra miles, or additional tasks, their willingness to perform with or without any additional remuneration on behalf of their organizations.

The study's use of a questionnaire and statistical methods are limited to quantitative methods, therefore further research can be conducted by adopting the same model but suing qualitative data from academics staffs. This will enable collecting unrestricted data from academics and include data regarding their feelings, opinions, motivations, thus enabling access to data on trends in thoughts and opinions.

\section{References}

Abdulrab, M., Zumrah, A. R., Alwaheeb, M. A., Al-Mamary, Y. H. S., \& AlTahitah, A. (2020). The Impact of Transformational Leadership and Psychological Empowerment on Organizational Citizenship Behaviors: A PLS-SEM Approach. Journal of Critical Reviews, 7(9), 908-917. 
Abdulrab, M., Zumrah, A. R., Almaamari, Q., Al-Tahitah, A. N., Isaac, O., \& Ameenf, A. (2018). The Role of Psychological Empowerment as a Mediating Variable between Perceived Organizational Support and Organizational Citizenship Behaviour in Malaysian Higher Education Institutions. International Journal of Management and Human Science.

Ahmad, I., \& Zafar, M. A. (2018). Impact of psychological contract fulfillment on organizational citizenship behavior: Mediating role of perceived organizational support. International Journal of Contemporary Hospitality Management, 30(2), 1001-1015.

Akosile, A. \& W. Olatokun (2019). Factors influencing knowledge sharing among academics in Bowen University, Nigeria. Journal of Librarianship and Information Science 6: 1-18.

Allen, D. G., Shore, L. M., \& Griffeth, R. W. (2003). The role of perceived organizational support and supportive human resource practices in the turnover process. Journal of Management, 29(1), 99-118.

Al-Mamary, Y. H. S. (2020). The impact of transformational leadership on organizational citizenship behaviour: Evidence from Malaysian higher education context. Human Systems Management, (Preprint), 1-13.

Al-Mamary, Y.H.S., Abdulrab, M., Alwaheeb, M.A. and Alshammari, N.G.M. (2020), "Factors impacting entrepreneurial intentions among university students in Saudi Arabia: testing an integrated model of TPB and EO", Education + Training, Vol. 62 No. 7/8, pp. 779-803.

Al-Mustapha, T., \& Olugbenga, A. O. (2016). Assessment of Traditional Human Resource Development Strategies of Construction Firms in North Western, Nigeria. Journal of Logistics, Informatics and Service Science, 3(2), 37-65.

Alshahrani, H., \& Rasmussen Pennington, D. (2018). "Why not use it more?" Sources of self-efficacy in researchers' use of social media for knowledge sharing. Journal of Documentation, 74(6), 1274-1292.

Alwaheeb, M., Abdulrab, M., Al-Mamary, Y., \& Mutahar, Y. (2020). Organizational commitment and academics' knowledge sharing: A review and directions for future research. International Journal of Scientific and Technology Research, 9(4), 3084-3091. 
Annansingh, F., Howell, K. E., Liu, S., \& Baptista Nunes, M. (2018). Academics' perception of knowledge sharing in higher education. International Journal of Educational Management, 32(6), 1001-1015.

Azman, N., Jantan, M., \& Sirat, M. (2011). Malaysia: Perspectives of University governance and management within the academic profession Changing Governance and Management in Higher Education (pp. 83-105): Springer.

Blau, P. M. (1968). Social exchange. International encyclopedia of the social sciences, 7, 452-457.

Blueprint, M. E. (2019). Blueprint 2015-2025 (Higher Education). Ministry of Education Malaysia, Putrajaya.

Bock, G. W., \& Kim, Y. G. (2002). Breaking the Myths of Rewards: An Exploratory Study of Attitudes about Knowledge Sharing. Information Resources Management Journal (IRMJ), 15(2), 14-21.

Bock, G.-W., Zmud, R. W., Kim, Y.-G., \& Lee, J.-N. (2005). Behavioral intention formation in knowledge sharing: Examining the roles of extrinsic motivators, social-psychological forces, and organizational climate. MIS Quarterly, 87-111.

Brante, I. , \& Sloka, B. (2021). Work-based Learning - Challenge for Competitive Vocational Education Experience of Latvia. Journal of Service, Innovation and Sustainable Development, 2(1), 62-71.

Cabrera, E. F., \& Cabrera, A. (2005). Fostering knowledge sharing through people management practices. The International Journal Of Human Resource Management, 16(5), 720-735.

Choi, S. Y., Kang, Y. S., \& Lee, H. (2008). The effects of socio-technical enablers on knowledge sharing: an exploratory examination. Journal of Information Science, 34(5), 742-754.

Chuymanee, K., \& Sorod, B.-o. (2018). The Development of a Knowledge Sharing Behavior Scale in the Thai Context. Journal of Community Development Research (Humanities and Social Sciences), 11(3), 27-38.

Davenport, E., \& Cronin, B. (2000). Knowledge management: semantic drift or conceptual shift? Journal of Education for library and information Science, 294306. 
Eisenberger, R., Huntington, R., Hutchison, S., \& Sowa, D. (1986). Perceived organizational support. Journal of Applied Psychology, 71(3), 500-507.

ETP. (2017). The Economic Transformation Programme (ETP) Prime Minister's Department: Performance Management \& Delivery Unit (PEMANDU) Retrieved from https://www.pemandu.gov.my/assets/publications/roadmaps/ETP_Roadmap.pdf.

E. J. Adaletey, \& T. J. George, (2018). The Relevance of Monitoring, Supervision And Evaluation of Stakeholder Participation In Electronic Governance Projects Implemented In Public Sector Institutions: A Review of Literature. IOSR Journal Of Humanities And Social Science (IOSR-JHSS), 6(4), 52-60.

Fauzi, M. A., Tan, C. N.-L., \& Ramayah, T. (2018). Knowledge sharing intention at Malaysian higher learning institutions: The academics' viewpoint. Knowledge Management \& E-Learning: An International Journal (KM\&EL), 10(2), 163-176.

Fullwood, R., Rowley, J., \& McLean, J. (2018). Exploring the factors that influence knowledge sharing between academics. Journal of Further and Higher Education, $1-13$.

Ghasemy, M., Hussin, S., Megat Daud, M. A. K., Md Nor, M., Ghavifekr, S., \& Kenayathulla, H. B. (2018). Issues in Malaysian higher education: a quantitative representation of the top five priorities, values, challenges, and solutions from the viewpoints of academic leaders. SAGE Open, 8(1), 2158244018755839.

Hair, J. F., Hult, G. T. M., Ringle, C. M., \& Sarstedt, M. (2017). A primer on partial least squares structural equation modeling (PLS-SEM). Los Angeles, Calif: Thousand Oaks: SAGE.

Hair, J. F., Hult, G. T. M., Ringle, C. M., \& Sarstedt, M. (2017). A primer on partial least squares structural equation modeling (PLS-SEM). Los Angeles, Calif: Thousand Oaks: SAGE.

Hair, J. F., Hult, G. T. M., Ringle, C., \& Sarstedt, M. (2014). A primer on partial least squares structural equation modeling (PLS-SEM). Thousand Oaks: Sage.

Hair, J. F. (2006). Multivariate data analysis: Pearson Education India.

Han, S. H., et al. (2016). Transformational leadership and knowledge sharing: Mediating roles of employee's empowerment, commitment, and citizenship behaviors. Journal of Workplace Learning, 28(3), 130-149. 
Hayes, A. F., \& Preacher, K. J. (2010). Quantifying and testing indirect effects in simple mediation models when the constituent paths are nonlinear. Multivariate behavioral research, 45(4), 627-660.

Henseler, J., Dijkstra, T. K., Sarstedt, M., Ringle, C. M., Diamantopoulos, A., Straub, D. W., \& Calantone, R. J. (2014). Common beliefs and reality about PLS: Comments on Rönkkö and Evermann (2013). Organizational Research Methods, 17(2), 182-209.

Henseler, J., Hubona, G., \& Ray, P. A. (2016). Using PLS path modeling in new technology research: updated guidelines. Industrial Management \& Data Systems, $116(1), 2-20$.

Jeung, C.-W., Yoon, H. J., \& Choi, M. (2017). Exploring the affective mechanism linking perceived organizational support and knowledge sharing intention: a moderated mediation model. Journal of Knowledge Management, 21(4), 946-960.

Jolaee, A., Nor, K. M., Khani, N., \& Yusoff, R. M. (2014). Factors affecting knowledge sharing intention among academic staff. International Journal of Educational Management, 28(4), 413-431.

Khari, C., \& Sinha, S. (2018). Organizational Spirituality and Knowledge Sharing: A Model of Multiple Mediation. Global Journal of Flexible Systems Management, 19(4), 337-348.

Krejcie, R. V., \& Morgan, D. W. (1970a). Determining sample size for research activities. Educational and psychological measurement, 30(3), 607-610.

Lee, J.-N. (2001). The impact of knowledge sharing, organizational capability and partnership quality on IS outsourcing success. Information \& Management, 38(5), 323-335.

Lu, L., Leung, K., \& Koch, P. T. (2006). Managerial Knowledge Sharing: The Role of Individual, Interpersonal, and Organizational Factors. Management and Organization Review, 2(1), 15-41.

Matar, I. (2018). The integration of knowledge management into the lebanese graphic design business sector. Journal of System and Management Sciences, 8(1), 61-82. 
Mousa., T. S., et al. (2019). The Impact of Attitude, Subjective Norm and Information Communications Technology on Knowledge Sharing among Academic Staff. International Journal of Psychosocial Rehabilitation, 23(02), 704 -718.

Nunnally, J. (1978). Psychometric methods: New York: McGraw-Hill.

Organ, D. W. (1988). Organizational citizenship behavior: The good soldier syndrome: Lexington Books/DC Heath and Com.

Pattanayak, S., Mishra, U. S., \& Dash, M. (2017). Mediating role of job satisfaction in the relationship between perceived organizational support and organizational citizenship behavior: An empirical study in indian insurance sector. International Journal of Applied Business and Economic Research, 15(10), 365-374.

Preacher, K. J., \& Hayes, A. F. (2008). Asymptotic and resampling strategies for assessing and comparing indirect effects in multiple mediator models. Behavior research methods, 40(3), 879-891.

Ramayah, T., Yeap, J. A. L., \& Ignatius, J. (2014). Assessing Knowledge Sharing Among Academics: A Validation of the Knowledge Sharing Behavior Scale (KSBS). Evaluation review, 38(2), 160-187.

Ridzuan, A. A., Sam, H. K., \& Adanan, M. A. (2008). Knowledge management practices in higher learning institutions in Sarawak. Asian Journal of University Education, 4(1), 69-89.

Sadegh, T., et al. (2018). Introducing a model of relationship between knowledge sharing behavior and organizational citizenship behavior and positively orientated organizational behavior: A two-wave study. International Journal of Knowledge Management 14(3): 21-36.

Sekaran, U. (2000). Research methods for business: A skill-building approach: John Wiley \& Sons.

Seonghee, K., \& Boryung, J. (2008). An analysis of faculty perceptions: Attitudes toward knowledge sharing and collaboration in an academic institution. Library and Information Science Research, 30(4), 282-290.

Tafti, H. F., Sarvestani, R. A., \& Hosseini, M. (2018). The role of trust and dependence on the performance of information systems in knowledge-sharing process in ICT of the municipality of Shiraz. Iranian Journal of Information Processing Management, 33(4), 1465-1492. 
Van Knippenberg, D., van Prooijen, J. W., \& Sleebos, E. (2015). Beyond social exchange: Collectivism's moderating role in the relationship between perceived organizational support and organizational citizenship behaviour. European Journal of Work and Organizational Psychology, 24(1), 152-160.

Wu, Y., \& Zhu, W. (2012). An integrated theoretical model for determinants of knowledge sharing behaviours. Kybernetes, 41(10), 1462-1482.

Zhang, R. (2011). Study on the influence of perceived organizational support and inter-organizational trust on organizational citizenship behaviors in technology alliances.

Zhou, Y., \& Zhang, Q. (2013). The role of leadership traits, style, and support behavior in knowledge sharing in university research teams: The moderating influence of organizational support. 